\title{
HISTOLOGICAL OBSERVATIONS ON MONTENEGRO'S REACTION IN MAN
}

\author{
Wilson mayrink (1), Antonio Pedro M. SChettini (2), Paul Williams (1), Pedro RASo (3), Paulo Araujo \\ MAgALHÃes (4), Antonio de Oliveira LIMA (5), Maria Norma MELO (1), Carlos Alberto da COSTA (6), Odair \\ GENARO (7), Magno DIAS (8) \& Marilene Suzan Marques MICHALICK (1).
}

\begin{abstract}
SUMMARY
The Montenegro skin test is widely used as a diagnostic method for American cutaneous leishmaniasis (ACL) but little is known about the histological changes that occur in the skin after administration of the antigen. This report is based on histological studies of biopsied material obtained, from inoculation sites, 48 hours after individuals had been given intradermal injectrons with a standardized Montenegro antigen. The material examined was obtained from four distinctly different test groups: naturally infected patients with parasitologically proved ACL and with positive Montenegro's reaction; individuals without previous history of $\mathrm{ACL}$ and not previously tested with Montenegro antigen; participants in anti-ACL. vaccine trials who developed positive reactions to Montenegro antigen after vaccination; other participants in vaccine trials who had negative Montenegro responses after vaccination or had served as controls in the trials. The histological pictures of each group are described and discussed. Histologically, the reactions of vaccinated individuals were indistinguishable from those with naturally acquired infections.
\end{abstract}

KEY WORDS: American Cutaneous leishmaniasis; Montenegro skin test; Histology of skin changes

\section{INTRODUCTION}

MONTENEGRO (1926) developed a skin test, using phenolized cultured promastigotes of Leishmania as antigen, 10 facilitate the diagnosis of American culaneous leishmaniasis (ACL). The subsequent studies of SALLES GOMES (1939) showed that Montenegro antigen provoked a delayed hypersensitivity reaction in individuals will $A(L$. He also recorded that lesions tended io decrease in size after patients had been skin tested with the antigen and suggested that a modification of the Montenegro test could provide the basis of a prophyllactic vaccine againsı ACL. A crude vaccine against $\mathrm{ACL}$ was developed and field

(1) Departamento de Parasitologia, Instituto de Ciências Biológicas da Universidade Federal de Minas Gerais. Caixa Postal 2486, 31270 Belo Horizonte, Minas Gerais, Brasil.

(2) SESAU/Manaus. Amazonas. Brasil

(3) Departamento de Patologia, Faculdade de Medicina da Universidade Federal de Minas Gerais, Belo Horizonte, Brasil.

(4) Ministério de Saúde, SUCAM, Caratinga, Minas Gerais, Brasil.

(5) Fundação Ataulfo Paiva, Rio de Janeiro, Brasil.

(6) Faculdade de Farmácia da Universidade Federal de Minas Gerais, Belo Horizonte, Brasil.

(7) Instituto Nacional de Pesquisas da Amazonia, Manaus, Amazonas, Brasil.

(8) Departamento de Ciências Biológicas da Universidade Federal de Ouro Preto, Ouro Preto, Minas Gerais, Brasil. 
MAYRINK, W.; SCHETTINI, A.P.M.; WILliaMS, P.; RASO, P.; MAGALHÃES, P.A.; LIMA, A. de O.; MELO, M.N.; COSTA, C.A. da; GENARO, O.; DIAS, M. \& MICHALICK, M.S.M. - Histological observations on Montenegro's reaction in man. Rev. Inst. Med. trop. S. Paulo, 31(4):256-261, 1989.

tested in the State of São Paulo about 50 years ago (PESSÔA \& PESTANA, 1939; PESSÔA, 1941 a,b). In the São Paulo trials, the efficacy of the vaccine was assessed by statistical comparison to the incidence of infection in vaccinated and unvaccinated groups.

The promising results obtained in the São Paulo studies were ignored for 34 years until MAYRINK et. al. (1979) developed a polyvalent killed promastigote vaccine and field tested it in a district of the municipio of Caratinga, State of Minas Gerais. The field trial in Caratinga was inconclusive because ACL disappeared from the study area during the period that observations were made. An important discovery in the Caratinga trials was the fact that a high proportion of vaccinated individuals showed changes in their responses to Montenegro antigen. The results suggested that the skin test could provide a means for assessing the degree of protection that developed from vaccination.

Emergency use of the experimental vaccine in the State of Espírito Santo (MAYRINK el. al., 1985) revealed a significant level of protection amongst individuals who became Montenegro positive after vaccination. Responses to Montenegro antigen were later used in field trials of the experimental vaccine conducted anongst 18-year-old army conscripts undergoing jungle training in the vicinity of Manaus, State of Amazonas (MAYRINK et al., 1986; ANTUNES el al., 1986). The Manaus trials showed that about $70 \%$ of vaccinated individuals were protected against ACL.

Alhough the Montenegro skin test is of proven value in the diagnosis of $\mathrm{ACL}$ and seems 10 be of utility in assessing vaccine prophyllaxis, linle is known aboul the histological changes that occur in the skin after intradernal injection of the antigen. Herein, we record histological changes induced by adninistration of Montenegro antigen to fout different groups of individuals.

\section{MATERIALS AND METHODS}

\section{Test groups}

Participants in the sludy were volunteers who gave written consent.

Group I: Nine patients with ACL were examined at the SUCAM clinic Caratinga,
Minas Gerais. ACL was diagnosed parasitologically and all had positive Montenegro's reaction. This constitutes the positive control group.

Group 1I: Five individuals had no history of $A C L$, had not been participants in trials of the experimental vaccine, and had not previously been tested with Montenegro antigen. This constitutes the negative control group.

Group III: It consisted of nine 18-year-old army conscripts in Manaus who were Montenegro negative before vaccination and had positive reactions to the antigen 35 days after receiving the second (last) dose of vaccine.

Group IV: Four army conscripts who participated in the Manaus trials formed this group. All were initially Montenegro negative. Two were still negative 35 days after receiving the second dose of vaccine. The other two were Montenegro negative after receiving the placebo.

\section{Montenegro antigen}

The antigen was prepared and used in the manner described by MELO et al. (1977), and was composed by pooling promastigotes of four stocks: IFLA/BR/67/PH8 (Leishmania amazonensis); MHOM/BR/70/M1176 (L. guyanensis); MHOM/BR/75/M2903 (L. braziliensis); MHOM/BR/60/BH6 (L. mexicana). The antigen contained 40 meg $\mathrm{N} / \mathrm{ml}$, with $10 \operatorname{mcg} \mathrm{N} / \mathrm{ml}$ of each stock, obtained by sonicating promastigotes.

\section{Vaccine}

This was prepared by the methods described by MAYRINK et al. (1979) and contained pooled promastigotes of five slocks: $\mathrm{MHOM} / \mathrm{BR} / 70 / \mathrm{M} 1176$, isolated from a case of cutaneous leishmaniasis in the State of Pará: $\mathrm{MHOM} / \mathrm{BR} / 60 / \mathrm{BH} 6$, isolated from a case of muco-cutaneous leishmaniasis in the State of Ceará: $\mathrm{MHOM} / \mathrm{BR} / 71 / \mathrm{BH} 49$, isolated from a case of dermal leishmaniasis in the State of Golás: IFLA/BR/67/PH8, isolated from a naturally infected sand fly captured in the State of Pará: $\mathrm{MHOM} / \mathrm{BR} / 73 / \mathrm{BH} 121$ isolated from a case of multiple dermal lesions, the patien living in the Rio Doce Valley of Minas Gerais. Each slock was cultured separatedly in LIT 
MAYRINK, W.; SCHETTINI, A.P.M.; WILliAMS, P.; RASO, P.; MAGALHÃES, P.A.; LiMA, A. de O.; MELO, M.N.; COSTA, C.A. da; GENARO, O.; DIAS, M. \& MICHALICK, M.S.M. - Histological observations on Montenegro's reaction in man. Rev. Inst. Med. trop. S. Paulo, 31(4):256-261, 1989.

mediun (CAMARGO, 1953) and harvested after seven days and pooled.

In those individuals who were vacinated, a freshly prepared vaccine containing $240 \mu \mathrm{g} / \mathrm{ml}$ of nitrogen was given in 1 wo doses, each of 1.5 ml, given with an interval of seven days. Bonh doses were detivered slowly by deep intranuscular infection.

\section{Histological studies}

Biopsies were laken when reading reactions to Montenegro antigen 48 hours after it has been administered intradermically. Skin fragments were fixed in $10 \%$ formalin (buffered to $\mathrm{pH}$ 7.2), embedded in paraffin wax, sectioned at $5 \mu \mathrm{m}$, and slained with haematoxylin and eosin.

\section{RESULTS}

The following histological patterns wero recorded in the four groups:

Group I (Fig. 1). There were multiple foci of chronic inflammatory reactions of moderate intensity in the superficial and deep reticulate dermis. The exudate was almosi entirely composed of mononuclear cells, with a few interspersed granulocytes. No giant Langhans cells were seen and there were no signs of granuloma formation. In one of the biopsies, there was a more pronounced reaction around sweal glands.

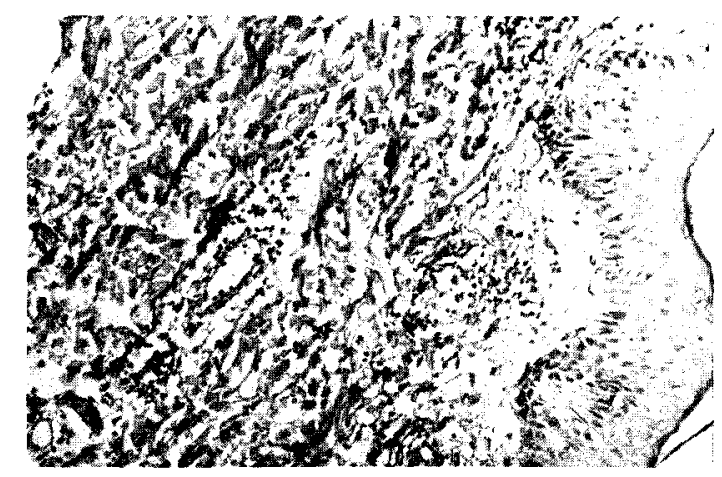

Hig. 1 - Histological section of a positive Montenegro ication in a patient with naturally-acquired ACl. (Group I) (64)
Group II (Fig. 2). A few sparsely distributed mononuclear cells were seen in the dermis.

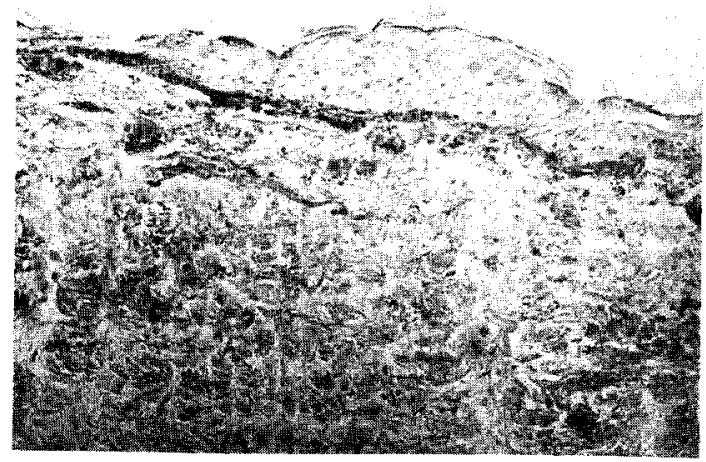

Fig. 2 - Histological section of a negative Montenegro reaction in a healthy individual not previously tested with the antigen (Group II) (X 640).

Group III (Fig. 3). There were multiple inflammatory perivascular and perianexial foci in the superficial and deep reticulate dermis, with some extensive foci and others confluent with each other. The exudate was almost exclusively composed of mononuclear cells but with scanty interspersed granulocytes. No giant Langhans cells were seen. Collagen fibres were normal, oedema was slight, and the epidermis was normal.

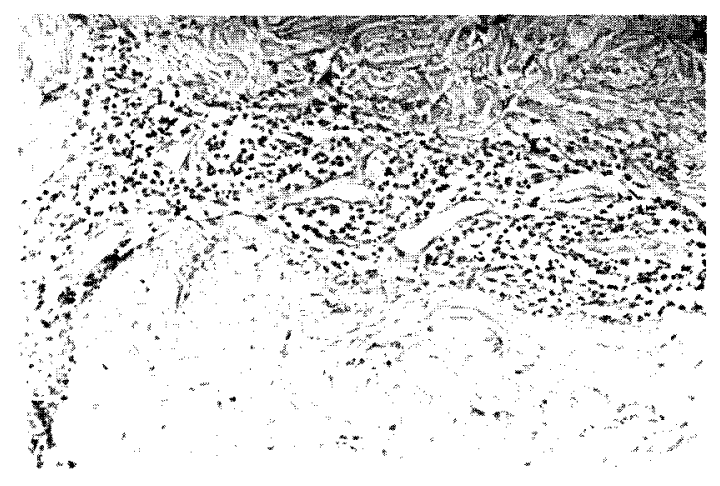

Fig. 3 - Histological section of a positive Montentegrs reaction in a vaccinated individual (Croup III) (X 640).

Group IV (Figs. 4 \& 5). Biopsies from the two vaccinated individuals who remain Montenegro negative were histologically 
MAYRINK, W.; SCHETTINI, A.P.M.; WILLIAMS, P.; RASO, P.; MAGALHÃES, P.A.; LIMA, A. de O.; MELO, M.N.; COSTA, C.A. da; GENARO, O.; DIAS, M. \& MICHALICK, M.S.M. - Histological observations on Montenegro's reaction in man. Rev. Inst. Med. trop. S. Paulo, 31(4):256-261, 1989.

similar to biopsies obtained from two members of the placebo group. In each of the four biopsies, there were perivascular and perianexial aggregations of mononuclear cells.

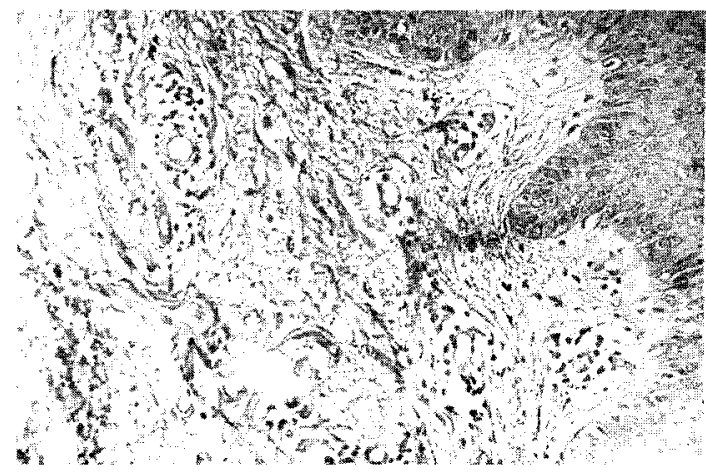

Fig. 4 - Histological section of a negative Montenegro reaction in an individual who received a placebo in a vaccine trial (Group IV) (X 640).

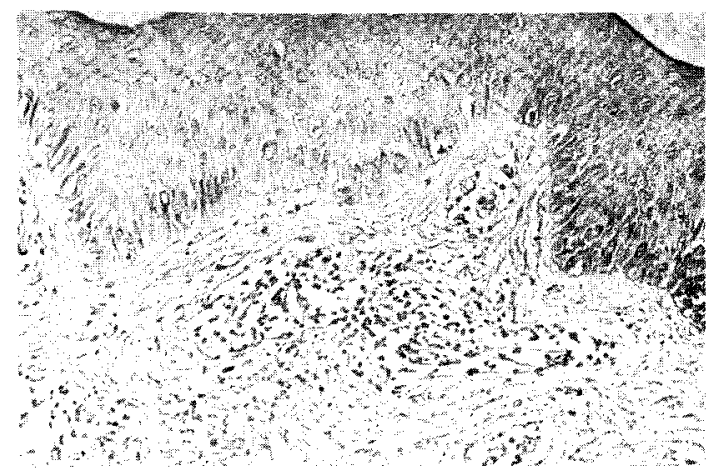

f.ig. 5 - Histological section of a negative Montenegro reaction in a vaccinated individual with an unchanged response to the antigen (ciroup IV) (X 640).

\section{DISCUSSION}

DHALIWAL \& LIEW (1987) distinguished between the tuberculin delayed-type hypersensitivity reaction and the earlier and more transient Jones-Mote response. The former is characterized histologically by infiltration of mononuclear cells at the site of antigen administration whereas there is an aggregation of basophils in the Jones-Mote reaction. Differentiation between these two types of delayed-type hypersensitivity is of importance in understanding the various inmunological processes involved in cutaneous leishmaniasis.

In experiments with BALB mice and. $\mathbf{L}$. major, DHALIWAL et al. (1985) found that immunization, by subcutaneous or intradermal routes, with formaldehyde killed promastigotes did not protect the mice when challenged. The immunized hosts displayed a heightened susceptibility to infection in comparison with nonimmunized, normal mice. These findings were explained by the later investigations of DHALIWAL \& LIEW (1987) and LIEW \& DHALIWAL (1987) who incorporated into their studies histological changes that occur at the site of inoculation of a test antigen. In material taken at the peak time for observing delayed-type hypersensitivity, it was found that reactions were of the Jones-Mote type, with scant mononuclear infiltration. In the BALB mouse/ L. major model, immunization with killed promastigotes did not afford protection but, in fact, created a situation in which possible target cells for the parasites were aggregated.

The present histological studies on the effects of Montenegro antigen in the dermis of human subjects gave results that differed markedly from the experimental observations already cited. It would be premature to attempt to explain the conflicting information: but factors such as the methods used in-preparing the immunizing agent, and/or the test antigen, and/or the administration of both, and/or the host/parasite combination studied, either individually or in various combinations, could explain the differences.

Clinical experience with Montenegro antigen as a diagnostic tool for ACL, together with field experience in assessing the efficacy of an anti-ACL vaccine, were the main reasons for obtaining biopsies $\mathbf{4 8}$ hours after giving the test antigen. Biopsies were, therefore, obtained at a time equivalent to the material studied by DHALIWAL \& LIEW (1987) and LIEW \& DHALIWAL (1987).

Apart from the material from individuals in group II (negative controls with minimal inflammatory reactions) the histological pictures in biopsies from the other three groups 
MAYRINK, W.; SCHETTINI, A.P.M.; WILliamS, P.; RASO, P.; MAGALHÃES, P.A.; LiMA, A. de O.; MELO, M.N.; COSTA, C.A. da; GENARO, O.; DIAS, M. \& MICHALICK, M.S.M. - Histological observations on Montenegro's reaction in man. Rev. Inst. Med. trop. S. Paulo, 31(4):256-261, 1989.

were qualitatively similar. There were no signs of a lones-Mote lype of reacion; the responses were of a luberculin lype and, herelore. indicalive that protective processes were operative.

Biopsies from groups I and III could nol be distinguished histologically in double blind tests. On this basis, it would seem that vaccination, when followed by clear cul changes in response to Montencero antigen, mimies the cellulat immunological alterations that lake place in naturally acquired ACl.. These histological data do not pove that a vaceinated individual with a ennverted Montenegro reaction is protected against ACL infection but merely that such an individual could be in an heightened immunological condition to resist against the parasites. Whether or not a vacinated individual is, indeed, protected against infection, the histological similarities between groups 1 and III suggest that Montenegro testing provides the simplest and least expensive field method for assessing the effectiveness of an anti-ACL vacine. However, it must be emplasized that a change in response to Montenegro antigen after vaccination does not provide firm evidence that an individual is protected against ACL.

Histologically: the group IV biopsies were qualiatively similar to those of groups I and III but quantitatively less intense. Such a situation is understandable for the two vaccinated individuals who remained Montenogu negative. It can be supposed that some degree of immunological stimulation ocurred in these two but was not revealed by the skin test. The inflammatory reaction observed in the other two, who were not vaceinated but received the placebo, has three possible explanations. The two soldiers, continuing their jungle raining in an $\mathrm{ACl}$ endemic area, were presumably exposed to the bites of sand flies naturally infected with Leishmania. Inoculation, by biting sand flies, of small numbers of in fective forms or, even, non-infective stages of Leishmania might have been sufficient stimulus for the observed immunohistological changes. Such changes, however, could have been induced merely by the two Montenegro skin lests that the two soldiers of the placebo group underwent. In the present instance, both of the suggested stimuli, combined, might have induced the histological changes.
The results presented herein are of relevance to the planning and assessment of tield trials of potential vaccines against infection by leishmania. The fact that Montenegro antigen, by itself, might initiate immunohistological changes is not surprizing because the antigen, like the vaccine used by MAYRINK et al. (1978, 1985, 1986) and ANTUNES el al. (1986), is prepared from killed promastigotes. Indeed, it was the regression of leishmanial lesions following skin testing with Montenegro anigen (SALLES GOMES, 1939) that led to the development of an anti-ACL vacine (PESSOA \& PESTANA, 1940; PESSÔA, 1941a,b). The possibility that Montenegro antigen might stimulate immunological changes does not invalidate the use of this skin test in evaluating vaccines in the field. Although similar imnunohistological changes were recorded in the skin of all individuals in group IV, all four were considered 10 be Montenegro negative when biopsies were obtained.

However, the results show the necessity to exclude from vaccine field trials those individuals who have initial Montenegro positive reactions but have no history of disease. Because vaccine field trials have to be carried out in endemic areas, it must be assumed that a certain proportion of the resident population are already immune to infection as a result of exposure to bites of naturally infected sand flies but receiving insufficient parasites to induce lesion formation.

\section{RESUMO}

Histologia da reação de Montenegro no homem após vacinação contra Leishmaniose Tegumentar Americana

Foi realizado o estudo histológico do material obtido nas biópsias do local de inoculaça do antigeno para teste de Montenegro (T.M.) nos seguintes grupos de individuos: I) Seis pacientes com leishmaniose cutânea comprovados parasitologicamente, com Montenegro positivo; II) Cinco individuos normais, nào residentes em zona endêmica, com Montenegro negativo; III) Nove soldados participantes de ensaios clínicos com vacina anti-LTA - MAYRINK e cols. 1979 e que tiveram o TM positivo 35 dias após vacinação. IV) Um último grupo consti- 
MAYRINK, W.; SCHETTINI, A.P.M.; WILliAMS, P.; RASO, P.; MAGALHĀES, P.A.; LIMA, A. de O.; MELO, M.N.; COSTA, C.A. da; GENARO, O.; DIAS, M. \& MICHALICK, M.S.M. - Histological observations on Montenegro's reaction in man. Rev. Inst. Med. trop. S. Paulo, 31(4):256-261, 1989.

tuido de quatro soldados, também participantes de ensaio clínico com a mesma vacina acima, dois vacinados que não mostraram TM positivo 35 dias após vacinação e dois que receberam placebo.

As biópsias foram realizadas 48 hs após a inoculação do antígeno. O material foi fixado em formol à $10 \%(\mathrm{pH} \mathrm{7.2)}$.

Histologicamente, excetivando o grupo II (controle negativo), os grupos I-III-IV mostraram diferenças quantitativas no infiltrado mononuclear. Os quadros histológicos de cada grupo são descritos e discutidos.

\section{ACKNOWLEDGEMENTS}

This study was supported financially by $\mathbf{F i}$ nanciadora de Estudos e Projetos, Ministério de Ciência e Tecnologia (FINEP-MCT) Consetho Nacional de Desenvolvimento Científico e Tecnológico (CNPq), Fundação de Amparo à Pesquisa do Estado de Minas Gerais (FAPEMIG) and World Health Organization (W.H.O.).

\section{REFERENCES}

1. ANTUNES, C.M.F.; MAYRINK, W.; MAGALHÃES, P.A.; COSTA, C.A. da; MELO, M.N.; DIAS, M.; MICHALICK, M.S.M.; WILLIAMS, P.; LIMA, A.O.; VIEIRA, J.B.F. \& SCHETTINI, A.P.M. - Controlled field trials of a vaccinc against New World cutaneous leishmaniasis. Int. J. Epidem., 15:572-580, 1986.

2. CAMARGO, E.P. - Growth and differentiation in Trypanosoma cruzi. Origin of melacyclic trypanosomes in liquid media. Rev. Inst. Med. trop. S. Paulo, 6:93-100, 1964

3. DHALIWAL, J.S.; LIEW, F.Y. \& COX, F.E.G. Specific suppressor T cells for delayed-1ype hypersensitivity in susceptible mice immunized against cutaneous leishmaniasis. Infect. Immun., 49:417-423, 1985.
4. DHALIWAL, J.S. \& LIEW, F.Y. - Induction of delayed-type hypersensitivity to Leishmania major and the concomitant acceleration of disease development in progressive murine cutaneous leishmaniasis. Infect. Immun. 55:645-651, 1987.

5. LIEW, F.Y. \& DHALIWAL, J.S. - Distinctive cellular immunity in genetically susceptible $B A L B / c$ mice recovered from Leishmania major infection or after subcutaneous immunization with killed parasites. J. Immunol., 138:4450-4456, 1987.

6. MAYRINK, W.; COSTA, C.A. da; MAGALHÃES, P.A.; MELO, M.N.; DIAS, M.; LIMA, A.O.; MICHALICK, M.S.M. \& WILLIAMS, P. - A field trial of a vaccine against american dermal leishmaniasis. Trans. roy. Soc. trop. Med. Hyg., 73:385-387, 1979.

7. MAYRINK, W.; WILLIAMS, P.; COSTA, C.A. da; MAGALHÃES, P.A.; MELO, M.N.; DIAS, M.; LIMA, A.O.; MICHALICK, M.S.M.; FERREIRA CARVALHO, E.; BARROS, G.C.; SESSA, P.A. \& ALENCAR, J.T.A. de - An experimental vaccine against American dermal leishmaniasis: experience in the State of Espírito Santo, Brazil. Ann. trop. Med. Parasit., 79:259-269, 1985.

8. MAYRINK, W.; ANTUNES, C.M.F.; COSTA, C.A da; MELO, M.N.; DIAS, M.; MICHALICK, M.S.M.; MAGALHÃES, P.A.; LIMA, A.O.\& WILLIAMS, P. - Further trials of a vaccine against American cutaneous leishmaniasis. Trans. roy. Soc. trop. Med. Hyg., 80:1001, 1986.

9. MELO, M.N.; MAYRINK, W.; COSTA, C.A. da; MAGALHÃES, P.A.; DIAS, M.; WILLIAMS, P.; ARAUJO, F.G.; COELHO, M.V.\& BATISTA, S.M. - Padronização do antígeno de Montenegro. Rev. Inst. Med. trop. S. Paulo, 19:161-164, 1977.

10. MONTENEGRO, J.-A cutis reação na leishnaniuse. An. Fac. Med. S. Paulo, 1:323-330, 1926.

11. PESSÔA, S.B. - Profilaxia da leishmaniose tegumentar no Estado de São Paulo. Folha Méd., 22:157-161, $1941 \mathrm{a}$.

12. PESSÔA, S.B. - Segunda nuia sobre a vacinacão preventiva na leishmaniose legumenar americana com leptomonas mortos. Rev. paul. Med., 19:1-9, 1941b.

13. PESSÓA, S.B. \& PESTANA, B.R. - Ensaio sobre a vacinação preventiva na leishmaniose legumentar americana com germes mortos. Rev. Biol. e Hig., , 10:112$118,1940$.

14. SALLES GOMES, L. - A intra-dermo-reação de Montenegro na Leishmaniose e outras pesquizas affins. Brasil-méd., 3(49):5-15, 1939.

Recebido para publicação en 13/12/1988. 